\title{
The Importance of Additional Teaching Materials to Develop Student Skills in Digital Era-Study on Radio Content for Multi-platform Media
}

\section{Endang Setiowati}

Communication Department - Broadcasting Specialized, Vocational Education Program of Universitas Indonesia, Depok, Indonesia

\section{Abstract}

Radio is still a promising business, therefore graduates of Vocational Education Program both from Broadcasting and Advertising can still expect a career in the Radio industry. One part that can be filled by the graduates is as a content writer. However, with the development of communication technology makes the radio distribution channel not only use one terrestrial channel but rather done multi platfor media.

Corresponding Author: Endang Setiowati endang.setiowati@vokasi .ui.ac.id

Received: 8 June 2018 Accepted: 17 July 2018 Published: 8 August 2018

Publishing services provided by Knowledge $\mathrm{E}$

(c) Endang Setiowati. This article is distributed under the terms of the Creative Commons

Attribution License, which permits unrestricted use and redistribution provided that the original author and source are credited.

Selection and Peer-review under the responsibility of the 2 nd ICVHE Conference Committee. Radio broadcast distribution channels beside using regular terrestrial channels are also done through new media such as Twitter, Instagram, Path, YouTube, and Facebook. This raises the need for radio content writers who understand how scripts can be integrated between broadcasts through terrestrial channels and those sent through social media. This article offers a solution to add material to some lectures both in broadcasting and advertising, so that graduates of Vocational educational Program can meet the needs of the radio industry for scriptwriters, content writers or social media officers. This article is the result of indepth interview and observation to two alumni of Vocational Broadcasting University of Indonesia who are employed as social media officer in two leading radio stations in Jakarta.

Keywords: radio script writing course, multi-paltform, media content

\section{Introduction}

The competitive landscape of Broadcast radio has changed dramatically since new audio technologies, such as satellite and web radio, as well as music downloading media (MP3's and iPod's) and mobile music services or mobile multimedia devices (cellphones and PDA's) have transformed the listening environment to consume radio. Yet, in the first decade of the new millennium, broadcast radio continues to hold its own in the face of many new competing audio technologies and the seismic shifts in 
its management and organizational structures. (Keith, The Radio Station: Broadcasting, Satellite, and Internet 8th Edition, 2010) [2].

In Indonesia, Television still dominates and became the main media, followed by the Internet that grew very rapidly in various age segments. This situation raises various assumptions about the existence of broadcasting radio, whether or not Radio is still has appropriate listeners and a promising business. Fortunately the assumptions were answered by The Nielsen Radio Audience Measurement (RAM) survey that the radio still has a loyal audience. Nielsen RAM is a radio hearing survey of over 8,400 respondents aged 10 and over in 11 cities in Indonesia (Jakarta, Bandung, Jogjakarta, Semarang, Surakarta, Surabaya, Denpasar, Medan, Palembang, Makassar and Banjarmasin) [14].

This survey conducted in the third quarter of 2016 that show 57\% of total radio listeners are from Generation Z and Millennials or future consumers. Currently 4 out of 10 radio listeners listen to the radio through a more personal mobile phone device. Nielsen RAM noted, although the internet grew rapidly in this quarter, it does not mean radio penetration is decreasing. Nielsen told that penetration of television media (96\%), Outdoor Media Room (52\%) and Internet (40\%), while radio penetration rate is quite high, about $38 \%$. This weekly penetration rate shows that radio media is still being listened to by about 20 million consumers in Indonesia. According to this research, Radio listeners in 11 cities in Indonesia at least spend an average time of 139 minutes per day listening radio. Radio listening time per week is growing year by year. If in 2014 radio listeners spend only 16 hours of radio time per week, these results continue to increase in 2015 (16 hours 14 minutes per week) and 2016 (16 hours 18 minutes) [14].

The use of cell phones to listen to the radio is due to the listening application of radio through smartphones both based on IOS or Android. How big a promising business for Radio in Indonesia can be seen in the research of the increasing of smartphone users, conducted by Databoks. The research said that smartphone users increased since 2016 where the number is 62.5 million people, while in 2017 is expected to increase to 74.5 million users and by the year 2019 is expected to reach 92 million users. (Pengguna Smartphone di Indonesia 2016-2019, 2016)

Radio broadcasting has now lead to digital radio broadcasting where digital radio is different from online radio. On the online radio, listeners need to connect with internet connection to enjoy radio broadcasting, while digital radio does not need internet. Features on digital radio even this more, not only sound, but also can display text and images in the radio menu screen. Now the criteria of radio crews such as announcers, 
producers, scriptwriters, and so on are also changing. Previously the criteria to be an announcer is only needed a good voice, now radio announcers must have an attractive appearance or good looking. Most of radio stations in Indonesia have already its own application and website. They try to be present in every platform. For example, Radio Prambors has got special content on YouTube. The challenge is how to prepare different content for each platform, Radio is not only relies on advertising revenue on analog radio as well, but is beginning to extend revenue sources to digital radio, hold events, and more. [6]

Based on interviews with Chandra Novriadi, Head of Research and Development Division of National Private Radio Association of Indonesia (PRSSNI) and Director of Radio Female and Commissioner of PT Masima Cipta Karya, the holding company of a group of companies in the field of radio broadcasting, that nowadays the media content is not to be broadcast through terrestrial distribution channels only, but also through other distribution platforms namely Twitter, Instagram, Path, YouTube and Facebook. Therefore the radio scriptwriter or content writer is currently split into two different people, the scriptwriter for the broadcast to be delivered by the announcers through the terrestrial channel, and another manages the script or content for social media. Both contents should be integrated. [19]

The selection of these five platforms is because based on Nielsen's research, the radio listener's contribution is dominated by $38 \%$ millennials, $x$ generation with $28 \%$, and $19 \% \mathrm{z}$ generation. While the radio listeners in the silent generation and baby boomers are relatively few, each contributing only $2 \%$ and $13 \%$. And this millennial generation also proved to be the largest smartphone users who use the application Twitter, Facebook, Instagram, YouTube, and Path. [6]

Radio is using the five platforms, is also because of the increasing number of their users. The number of Facebook users in Indonesia has increased compared to, at the end of 2014, the number of monthly active users Facebook in Indonesia is still recorded as 77 million, in 2015 rose to 82 million users, while in the first 2 quarters of 2016 the users has reached to 88 million, said Sri Widowati, Head of Facebook Indonesia. [10] While Instagram users in Indonesia is numbered 22 million monthly users. [8]. Twitter users in Indonesia reach 50 millions users in 2016 and being the biggest three in the world before US and India. [9] Path as the fourth platform used by radio has the largest number of users coming from Indonesia. At the end of 2013 alone Path users worldwide is 20 million users, and 4 million of them are from Indonesia. [15]. The amazing number of new media users is YouTube users. Worldwide YouTube users are 1 billion viewers per day. Among the 1 billion YouTube viewers turned out Indonesia became one of 
the largest YouTube access countries in Asia Pacific. By 2015, the amount of time Indonesians spent watching YouTube (watch time) increased by $130 \%$ compared to last year. In fact, when combined with YouTube users from smartphone devices, the number of hours they watch increases to $250 \%$, or 2.5 times higher than in 2014 . This number is believed to be increasing every year. [18]

\section{Conceptual Framework}

Radio is a mass media that is personal. Writing a script for radio broadcasting should be short and simple. A scriptwriter must write for the ears not for the eyes, however we learn how to write at the very beginning is to write for the eyes. The words should not be the words of the sensational tabloid newspapers, but the script writer should not be afraid of using informal language when appropriate. A good story will almost write itself. A radio script writer should write as we speak, whether in colloquial English or Indonesia, should write with short sentences and one thought per sentence. [1]

Writing words to be heard by the ear is quite different from words to be read by the eye. The layout of sentences, their order and construction has to be thought through in order to be totally clear and unambiguous at their first hearing. The listener does not have the possibility of re-hearing something. It must make sense first time, and this places a special responsibility on the radio writer. So whether we are writing a 15-minute talk, a one-minute voice piece or a cue to a recorded interview, the basic 'rules' of radio writing - and the pitfalls - need to be simply stated. [4]

Radio Script Requirements are as mention follows: [4]

1. Use speech and personal language (write the way you talk)

2. Create a specific sentence-Keep It Short and Simple

3. Reduce abbreviations commonly used in writing languages, except the usual abbreviations.

4. Pay attention to cutting words and phrases

5. The Position of the source should be writing at the beginning of the name. For example, 'Minister of Communication and Information, Rudyantara said...'.

6. Make sure the spelling in writing the person's name and give the way of pronunciation especially for foreign names brackets. Example: Hugh Grant (hyu gran); Louis Armstrong (lui armstrong) 
7. Avoid third person pronouns.

8. The mention of the age of a person if it is needed only, but must be written completely not like in the printed media news in brackets

9. Number writing:

- For the numbers 1 to 11 are written with the letter. For example, 'Eleven hours after the plane was declared lost.....

- For numbers above 11 are written with letters. For example, '35 days before the elections...'.

- For very large numbers are written with a combination of numbers and letter. For example, 'As many as 75 thousand people meet at Gelora Senayan...'.

Social Media used by radio are Facebook, Instagram, Twitter, Path and YouTube. Path, YouTube, and Instagram is the medium of image or video, then there should be someone who can make graphic design, photo or video. So to be a social media content manager, one should be able to photograph, create video and graphic design. The person is in a Digital Media sub department. Under the Content Manager, which also supervise the Radio and Mobile Apps Department. [19]

In the curriculum taught today, for 14 meetings, students are taught only to write the script to be delivered by the announcers for analog radio or terrestrial distribution channel. The materials for video and photos have been obtained in photography and videography courses. The broadcasting students did not get the graphic design material. While the advertising students got two graphic design courses, but they did not get any videography and video editing material. Although they got the advertising photography, they still need the videography.

\section{Methodology}

This study used a qualitative approach, which is an approach to doing researchoriented on the symptoms that are natural. Therefore, the nature of this research and basic or naturalistic naturalness nature and cannot be done in a laboratory but had to plunge in the field. [5]

The method used to collect data is by conducting in-depth interviews and observation. [3] Observations have done first, is to monitor the integrated content between the airing content in radio and the content in social media. The second was interviewing the 
alumni of the Vocational Broadcasting who handle Social Media in 2 leading stations Gen FM and Bahana FM.

The informants are:

1. Nadilla - Social Media Officer at Bahana FM Jakarta

2. Dhaifina - Social Media Officer at Gen FM

\section{Result}

\subsection{Integrated between on air program and Instagram}

On Thursday, May 18, 2017 is the day of the International Museum, where the National Museum makes an event that when people visiting the National Museum in that day will be free of charge. In order for many people who are interested in the program and go to the national museum then made also a graphic image as a promotion in Instagram such as in Figure 1.

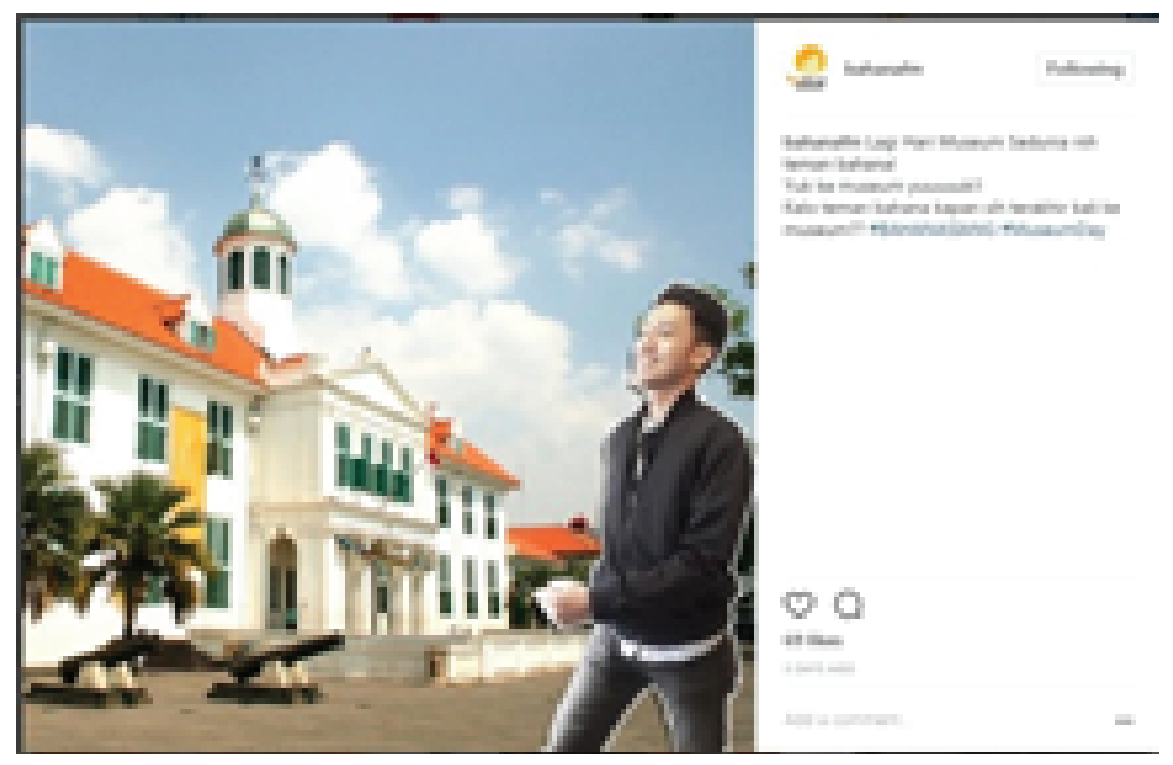

Figure 1: Instagram message integrated with on-air program.

\subsection{Integrated off-air, on-air program and Instagram}

Gen FM has an off air program in the form of a workshop that teaches listeners how to turn a comic into a radio drama. The program was held at several universities at different times. If the promotion of the show is only broadcast on the Gen FM as a 
media crosshairs the listener will forget where and when it will be held its activities. Therefore they also create similar messages in Instagram as seen in Figure 2.

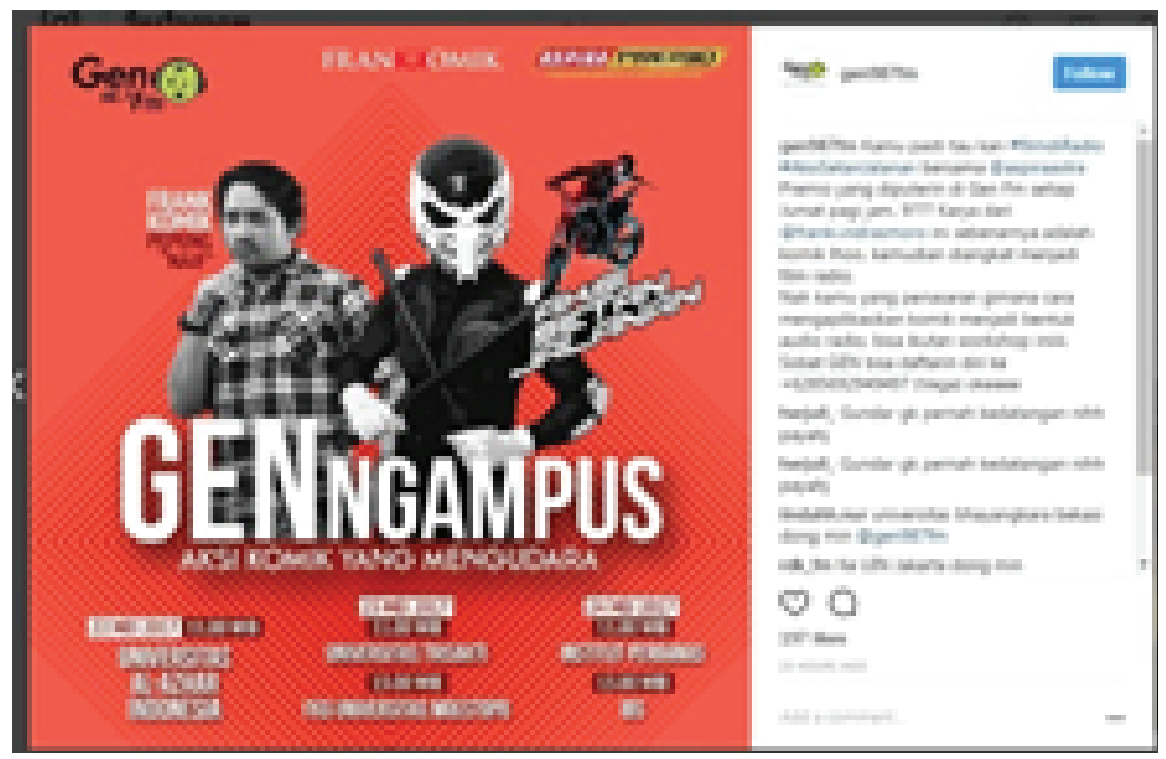

Figure 2: Integrated Off-air, on-air program and Instagram.

\subsection{Integration between On-air quiz and Instagram}

Radio Bahana created a quiz conducted from May 18 to 22, 2016 that provides free tickets to watch 'Pirates of The Caribbean: Salazars Revenge', for 10 people each of whom will get 3 free tickets. The show itself is on May 24, 2017 at XXI Plaza Senayan. Quizzes are broadcast on air programs in parts of the day. But listeners can answer it through Instagram. On Instagram every day will be shown different pictures of the movie to attract the interest of the listener. One of the pictures is shown in Figure 3.

\subsection{Integration between on-air program Instagram and YouTube}

One day Bahana FM invited the group band Gigi to fill the Bahana Morning Sequence namely 'Tika Udjo on Bahana FM'. At this event social media officers must make a video of their appearance in the program and posted to Instagram and mention if the listeners want to see the whole program, they can see the recordings on Bahana FM channel on YouTube. As seen as in Figure 4. 


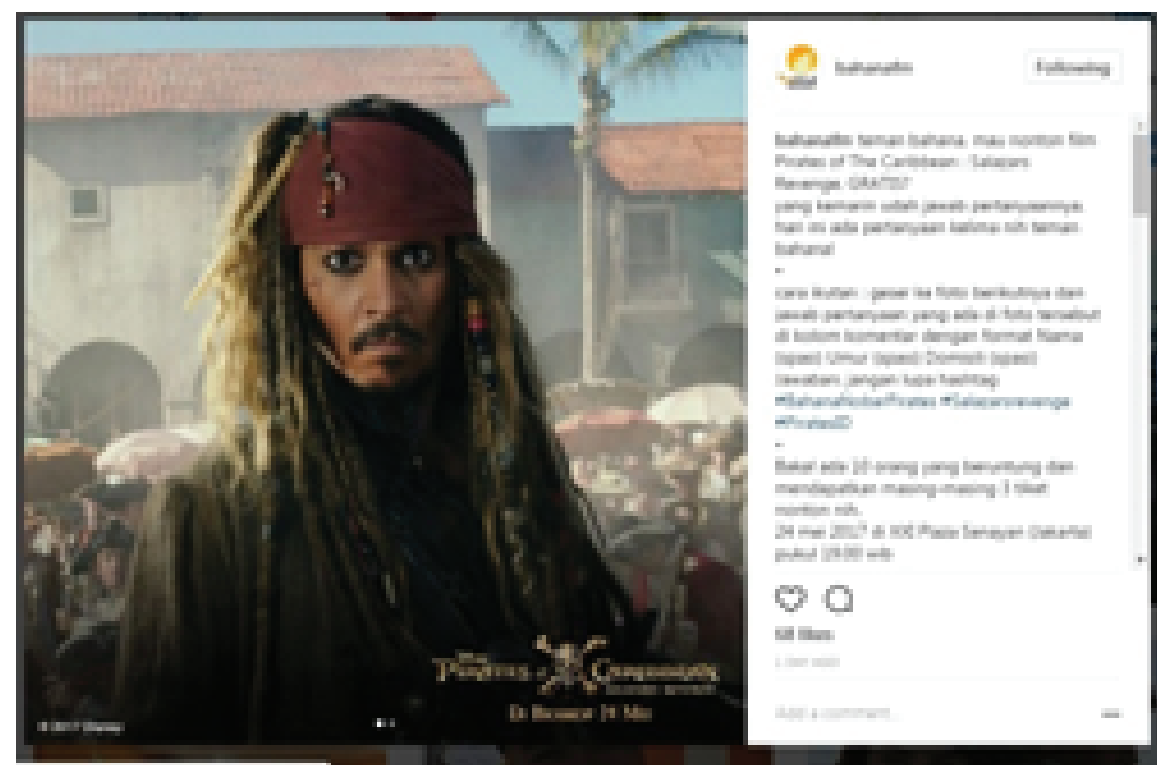

Figure 3: Instagram message-integrated quiz.

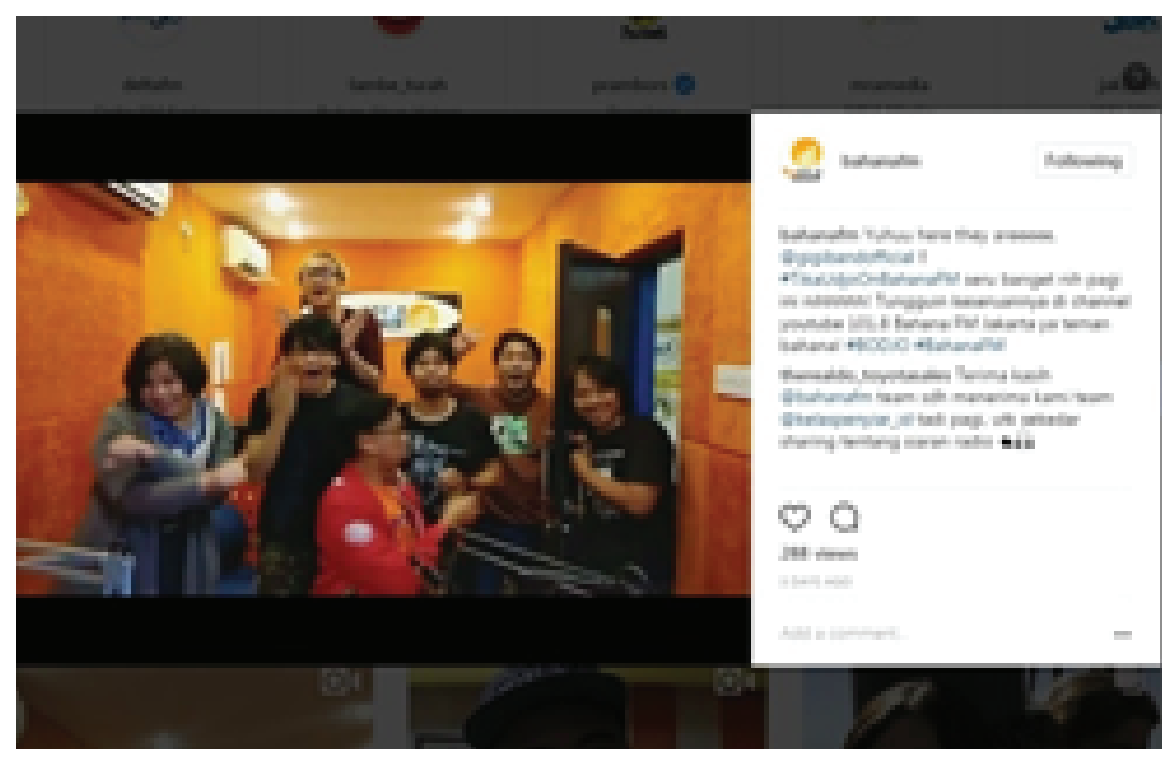

Figure 4: Integrated on-air program, Instagram, and YouTube.

\subsection{Integration between on-air program and Twitter}

In Gen FM there is a program called 'Gen Tulatit' which is a song request program. In order to attract the listeners to participate in the program, the social media officer should make a tweet in Twitter regarding the beginning of the program in the same time or directly after the announcer opening the program. She is also has to make an Instagram message by putting interested figure such as caricature that she made or take from somewhere with the message is still invitation to participate to the program. As seen in Figures 5 and 6. 


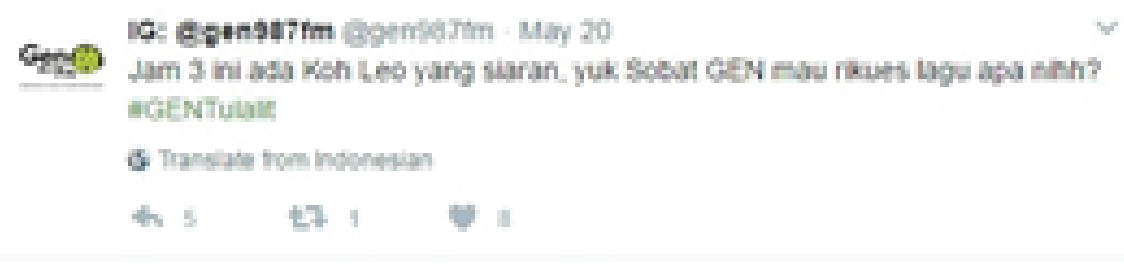

Figure 5: Message in Twitter.

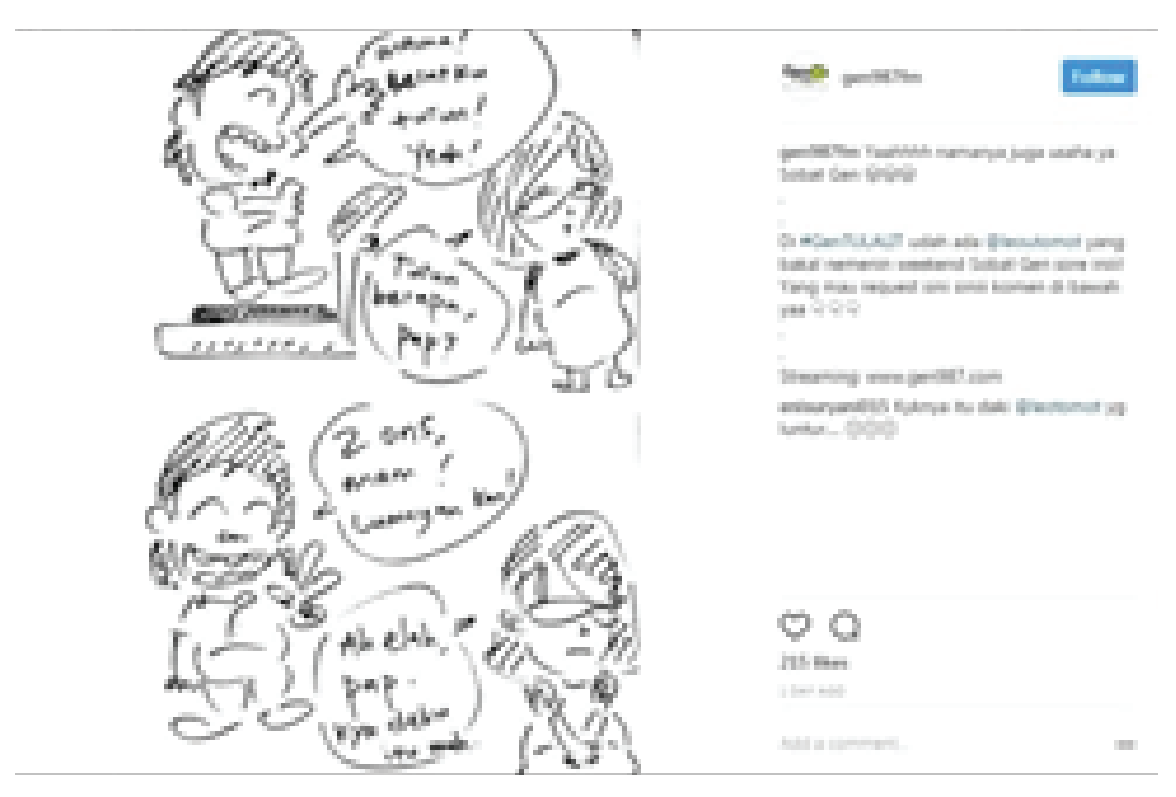

Figure 6: Message in Instagram.

\subsection{Discussion}

Based on interviews with the two informants, they said that the difficulty they face at the beginning of getting a job as a social media officer, is when working on graphic design, such as making a poster for an online promotion or promotion of a radio program. They say a minimum if they are taught the use of Adobe Photoshop they have no trouble. It would be even better if they were also taught graphic design.

They do not have any problems when they get the task of doing video editing, and taking videos or photos, this is because they get video and photo material in some broadcasting courses.

According to the observer, actually the material about graphic design which is the subject matter of the Advertising department can also be given to the broadcasting students by entering this material in several lecture programs from several subjects such as the writing of radio script, production and distribution of new media, and Web programming. Similarly, for student advertising can also be taught videography 
and video editing that enter as unit of lectures in several courses. This can provide additional skills for both broadcasting and advertising students.

\section{Conclusion and Recommendation}

\subsection{Conclusion}

1. Broadcasting students need additional materials for graphic design so that they can meet the needs of the industry, especially the radio industry in a position as a social media officer

2. Advertising students can also work in the radio industry as social media officers, but they must be provided with courses related to videography and photography.

\subsection{Recommendation}

1. For broadcasting students the design graphic materials could be put as some several subjects in several lectures such as radio script writing, production and distribution new media and web programming

2. For advertising students the videography and video editing could be put in Production and Distribution Digital Media lecture, while the photography material has been taught in Advertising Photography lecture.

\section{References}

\section{Book}

[1] Chantler, P., \& Stewart, P. (2003). Basic Rodio Journalism. Burlington, MA: Focal Press.

[2] Keith, M. C. (2010). The Radio Station: Broadcasting, Satellite, and Internet 8th Edition. Burlington, MA: Focal Press.

[3] Kriyantono, R. (2010). Teknik Praktis Riset Komunikasi. Jakarta: Kencana Prenada Media.

[4] McLeish, R. (2007). Radio Production: A Manual for Broadcasters 5th Edition. Burlington MA: Focal Press.

[5] Neuman, W. L. (2003). Social Research Methods: Qualitative and Quantitative Approaches. Fifth Edition. Boston: Pearson Education. 


\section{Internet}

[6] Azzahra, M. H. (2016, November 8). Maria Hudaibyah Azzahra. Retrieved March 1, 2017, from 57\% Pendengar Radio Adalah Generasi Milenial dan X: https://swa.co.id/swa/trends/business-research/57-pendengar-radio-adalahgenerasi-milenial-dan- $x$

[7] Chantler, P., \& Stewart, P. (2003). Basic Radio Journalism. Burlington, MA: Focal Press.

[8] Fajrina, H. N. (2016, June 27). Ada 22 Juta Pengguna Aktif Instagram dari Indonesia. Retrieved March 1, 2017, from CNN Indonesia: http://www.cnnindonesia.com/ teknologi/20160623112758-185-140353/ada-22-juta-pengguna-aktif-instagramdari-indonesia/

[9] Hasibuan, N. A. (2015, March 15). Jumlah Pengguna Twitter di Indonesia Akhirnya Terungkap. Retrieved March 1, 2017, from CNN Indonesia: http: //www.cnnindonesia.com/teknologi/20150326141025-185-42076/jumlahpengguna-twitter-di-indonesia-akhirnya-terungkap/

[10] Jusuf, O. (2016, October 10). Jumlah Pengguna Facebook di Indonesia Terus Bertambah. Retrieved March 1, 2017, from Kompas.Com: http://tekno.kompas.com/read/ 2016/10/20/17062397/jumlah.pengguna.facebook.di.indonesia.terus.bertambah

[11] Keith, M. C. (1987). Radio Programming:Consultancy and Formatics. Boston: Focal Press.

[12] Keith, M. C. (2010). The Radio Station: Broadcasting, Satellite, and Internet 8th Edition. Burlington, MA: Focal Press.

[13] Kriyantono, R. (2010). Teknik Praktis Riset Komunikasi. Jakarta: Kencana Prenada Media.

[14] Lubis, M. (2016, November 7). Radio Masih Memiliki Tempat Di Hati Pendengarnya. Retrieved Maret 22, 2017, from Nielsen.Com: http://www.nielsen.com/id/en/ press-room/2016/RADIO-MASIH-MEMILIKI-TEMPAT-DI-HATI-PENDENGARNYA. html

[15] Malau, I. L., \& Chandrataruna, M. (2013, November 1). Indonesia, Pengguna Path Terbesar di Dunia. Retrieved March 5, 2017, from Viva.Co.Id: http://teknologi.news. viva.co.id/news/read/455472-indonesia-pengguna-path-terbesar-di-dunia

[16] McLeish, R. (2007). Radio Production: A Manual for Broadcasters 5th Edition. Burlington MA: Focal Press.

[17] Neuman, W. L. (2003). Social Research Methods: Qualitative and Quantitative Approaches. Fifth Edition. Boston: Pearson Education. 
[18] Nistanto, R. K. (2015, October 20). Indonesia, Penonton YouTube Terbesar se-Asia Pasifik. Retrieved March 1, 2017, from Kompas.Com: http://tekno.kompas.com/ $\mathrm{read} / 2015 / 10 / 20 / 17315317 /$ Indonesia.Penonton.YouTube.Terbesar.se-Asia.Pasifik

[19] Novriadi, C. (2017, Maret 7). Membuat Naskah Radio untuk Multi Platform Channel. (E. Setiowati, Interviewer)

[20] O’Day, D. (1990). Great Radio Promotions and Contests. Los Angeles: Dan O'Day Publisher.

[21] Pengguna Smartphone di Indonesia 2016-2019. (2016, August 8). Retrieved March 22, 2017, from Katadata Indonesia: http://databoks.katadata.co.id/datapublish/ 2016/08/08/pengguna-smartphone-di-indonesia-2016-2019

[22] Warren, S. (2005). Radio: The Book. 4th Edition. Burlington, MA: Focal Press. 